\title{
Proximate composition, physicochemical properties and sensory qualities of salad cream from corn and tigernut starch blends
}

\author{
Oke Emmanuel Kehinde ${ }^{1}$, Idowu Michael Ayodele ${ }^{1}$, \\ Ojo Oladimeji George ${ }^{1}$, Adeleke Rafiat Bamidele ${ }^{1}$, \\ Adeyeye Samuel Ayofemi Olalekan ${ }^{2}$
}

\author{
1 - Federal University of Agriculture, Abeokuta, Nigeria. \\ 2 - Ton Duc Thang University, Ho Chi Minh City, Vietnam
}

\section{Keywords:}

Corn

Tigernut

Starch

Salad cream

\section{Article history:}

Received 27.02.2020

Received in revised

form 11.06.2020

Accepted 27.12.2020

\section{Corresponding}

author:

\section{Oke}

Emmanuel Kehinde

E-mail:

kennyoke35@

gmail.com

DOI: $10.24263 / 2304-$

974X-2020-9-4-8

\section{Abstract}

Introduction. This study was carried out to determine the proximate composition, physicochemical properties and sensory qualities of salad cream from corn and tigernut starch blends

Materials and methods. Yellow variety of tigernut and corn was sorted from dirt, washed, soaked for $24 \mathrm{hrs}$ and was wet milled into slurry using a laboratory hammer milling machine. The resulting slurry was filtered through muslin cloth and allowed to sediment for $3 \mathrm{hrs}$, after which the sediment was decanted, dried in a cabinet dryer and milled to obtain starch. Salad cream was produced from the blends of corn and tigernut starch with other ingredients.

Results and discussion. Moisture content, total ash, crude fat, crude protein and carbohydrate of the salad cream from the starch blends of corn and tigernut ranged from 51.50 to $59.58 \%, 0.33$ to $0.58 \%, 23.05$ to $24.78 \%, 0.65$ to $1.16 \%$ and 14.31 to $24.41 \%$ respectively. The interaction effect of corn and tigernut starch does not have any significant $(p>0.05)$ effect on the moisture content, total ash, crude fat, crude protein and carbohydrate of the salad cream from corn and tigernut starch. The moisture content of salad cream obtained in this study can affect its quality and its shelf stability. Salad cream from corn-tigernut starch at 90\%:10\% had the highest total ash and crude protein while salad cream from corn-tigernut starch at 10:90\% had the lowest total ash and crude protein. However, a progressive increase in total ash content was observed with the addition of corn starch. The values for the crude fat content of salad cream from corn-tigernut starch were similar. The interaction effect of corn and tigernut starch had a significant $(p<0.05)$ effect on the starch content and total titratable acidity. Sugar and Starch content ranged from 2.67 to $9.50 \%$ and 4.14 to $11.45 \%$ respectively, salad cream from corn-tigernut starch at 10\%:90\% had the highest value while salad cream from corn-tigernut starch at 70:30\% had the lowest value for sugar and starch content. The $\mathrm{pH}$, total titratable acidity and viscosity were $3.57-3.77,0.32-0.69 \%$ and 472-1683 $\mathrm{Pa} \cdot \mathrm{s}$ respectively. The solution process to the optimization of salad cream from corn and tigernut starch blend is $90 \%$ corn starch and $10 \%$ tigernut starch. However, optimized salad cream of $90 \%$ corn starch and $10 \%$ tigernut starch and commercial salad cream (Heinz salad cream) was most preferred by the panelist in term of their sensory attributes.

Conclusion. Salad cream from corn and tigernut starch had desirable physicochemical properties and has a compared sensory attributes with the commercial salad cream. Therefore, an acceptable salad cream can be produced up to $10 \%$ substitution of tigernut starch with corn starch. 


\section{Introduction}

Starch has been a key carbohydrate storage produce in all plants with green parts containing chlorophyll. It is economically accessible and commonly used in many facets of life for the manufacture of industrial products. The distinctive characteristic of starch which enhances its use basically includes biocompatibility, biodegradability, gelation and modification according to its potential usage $[1,2,3]$. Starch exists as the most essential carbohydrate in the human diet and in large quantity in many staple foods. Starch usually contains 20 to $25 \%$ amylose and 75 to $80 \%$ amylopectin by weight [4]. Starches are extracted from a number of different starchy raw materials, such as barley, maize, rice, sweetpotato, and cassava. Sweetpotato and cassava are two major starchy root and tuber crops used in many tropical countries [5]. However, information is still scanty on starch from tigernut. Tigernut (Cyperusesculentus $\mathrm{L}$ ) is an underutilized crop which belongs to the division Magnoliophyta, Class-liliopsida, order-cyperales and family-cyperaceae and was found to be a cosmopolitan perennial crop of the same genus as the papyrus plant. Other names of the plant are earth almond as well as yellow nut grass $[6,7]$. It is locally called "aya" in Hausa; "akiawusa" in Igbo; "ofio" in Yoruba and "isipaccara" in Effik most especially in Nigeria. Tigernut is safe to eat, sweet, nutty, flavoured tubers which consist of protein, carbohydrate, sugars, fat and fibre [8].Tigernut tuber exist in different varieties in Nigeria, but the two major varieties include, yellow and brown. It is an essential food crop for some certain tribes in Africa, tigernuts are often collected and eaten raw, baked as a vegetable, roasted or dried and ground to flour [8]. Tigernut tubers are rich in carbohydrate, starch and dietary fiber [9]. According to Adama et al. [3], extraction of tigernut starch gives an odourless, brilliant white or off-white non-hygroscopic powder with yields changing from as low as 14 to $37 \%$ depending on the volume and flesh of the tubers or nut.

Salad cream is a creamy, yellow condiment based on an emulsion of about $25-50 \%$ of oil in water, it is prepared from ingredients such as distilled vinegar, vegetable oil, water, sugar, mustard, salt, egg yolks, modified corn flour / starch, xantham gum and guar gum as stabilizers and riboflavin for colouring [10]. It can also be described as a readymade creamywhite dressing with a flowing consistency and uniformity for eating salad, (mixture of raw vegetable). It can be prepared with various ingredients such as modified maize flour which serves as the starting raw material $[11,10]$. In order to reduce the overdependence of corn which might not readily be available throughout the year due to seasonal variations, there is need to produce salad cream with or without the use of corn starch by substituting other local crop such as tigernut. Corn starch substituted with tigernut starch can be used in appropriate proportion thereby enhancing the nutritional quality and versatility of the salad cream. It can also increase its usefulness in food industry and serve as a better raw material for food products. However, there is dearth of information on salad cream from corn starch and tigernut starch.

The main objective of the study is to determine the proximate composition, physicochemical properties and sensory qualities of salad cream produced from corn and tigernut starch blends.

\section{Materials and methods}

\section{Materials}

The yellow variety of tigernut and corn, vegetable oil, egg yolk, vinegar, sugar, mustard paste, salt, flavoring and colouring was obtained at Eleweran market in Abeokuta, Ogun state, Nigeria 


\section{Methods}

\section{Extraction of starch from corn}

The corn starch was prepared according to the method described by Yao et al. [12]. Corn grains are free from dirt and other foreign materials like stones, sticks and leaves were weighed and cracked into grits. The grits were soaked in water for $24 \mathrm{hrs}$ with occasional changing of water to prevent fermentation. Then, the steeped grits was drained and wet milled using laboratory hammer mill (Fritsch, D-55743, Idar-oberstein-Germany) with warm water into fine slurry. The resulting slurry was sieved with muslin cloth and allowed to sediment for $3 \mathrm{hrs}$. The filtered and sedimented starch was decanted, dewatered and dried in a cabinet drier $\left(65^{\circ} \mathrm{C}, 6 \mathrm{~h}\right)$. The dried corn starch was milled using a laboratory hammer mill and also sieved using 400mesh sieves.

\section{Extraction of starch from tigernut}

The method described by Adama et al. [3] was used for extraction of tigernut starch. The dried tigernut tubers were sorted from dirt and washed. The washed tuber was soaked in sodium metabisulphite solution at room temperature $\left(27^{\circ} \mathrm{C}\right)$. Thereafter, the tuber was removed and wet milled into slurry using a laboratory hammer milling machine (Fritsch, D55743, Idar-oberstein-Germany). The paste was then dispersed in a large volume of $1 \%$ sodium metabisulphite solution and filtered through muslin cloth. The suspension was centrifuged at 3500 revolution per minute for 10 mins to ease the removal of dirt. The supernatant was then carefully decanted and the mucilage scraped off. The process was repeated for the period of three times with the mucilage on the starch been scraped constantly until a pure starch is obtained. The resulting starch was dried in the sun and further dried at $60{ }^{\circ} \mathrm{C}$ in a hot air oven, milled, weighed and stored in an airtight bag.

\section{Formulation of corn and tigernut starch blends for salad cream}

D-optimal mixture design was used to produce the percentage of corn and tigernut starch blends by combining corn and tigernut starch at 10\%:90\%, 90\%:10\%, 50\%:50\%, 70\%:30\%, 90\%:10\%, 30\%:70\%, 90\%:10\%, 10\%:90\% and 50\%:50\% respectively.

\section{Production of salad cream from corn and tigernut starch}

The method described by Sanni et al. [13] was used for the preparation of salad cream from corn and tigernut starch. The salad cream was produced from nine blends formulation of corn-tigernut starch. The tigernut starch, corn starch, mustard, sugar, salt and water was weighed into a cooking pot, stirred and brought for heating at $90{ }^{\circ} \mathrm{C}$ then was cooled to temperature $\left(8^{\circ} \mathrm{C}\right)$. The egg yolk and oil was then stirred into the slurry followed by the vinegar which was added gradually and boiled for $5 \mathrm{~min}$. The slurry of each blend was poured into labeled sterilized jars and stored in a refrigerated storage condition.

\section{Proximate composition of salad cream made from corn and tigernut starch}

Moisture content, total ash, crude fat and crude protein of salad cream from corn and tigernut starch was analyzed using the method described by AOAC [14], while carbohydrate content was determined using difference method. 


\section{Physico-chemical properties of salad cream from corn and tigernut starch}

pH determination. The $\mathrm{pH}$ meter was standardized with standard buffer solution of 4 . 0 . and 7.0. The $\mathrm{pH}$ was measured by inserting directly the electrodes into $10 \mathrm{ml}$ beaker containing the sample.

Determination of titratable acidity. Titratable acidity was determined according to the method described by Patterson et al. [15]. $1 \mathrm{~g}$ of the portion of the sample was weighed and put into $50 \mathrm{ml}$ centrifuge tube respectively. $10 \mathrm{ml}$ of distilled water was then added to each tube to dissolve each respectively and then flitted. $1 \mathrm{ml}$ aliquot of each solution was taken into another $50 \mathrm{ml}$ centrifuge tube and $10 \mathrm{ml}$ of distilled water was added to dilute the sample because it is highly colored. $10 \mathrm{ml}$ of the diluent was titrated against $0.1 \mathrm{~N} \mathrm{NaOH}$ solution using phenolphthalein ( 2 drops) indicator, until a pink colour is observed then percentage titratable acidity was calculated.

Determination of total sugar and starch contents. Sugar and starch contents were determined with the method of Dubois et al. [16] as described by Eke-Ejiofor and Kiin Kabari [17]. Hot ethanol was used to extract starch and sugar from corn-tigernut salad sample. The extract (supernatant) and digest (from the residue) was quantified calorimetrically for sugar and starch respectively, using phenol-sulphuric acid as the colour developing reagent; and absorbance read at $490 \mathrm{~nm}$ wave length. Corn-tigernut salad sample $(20 \mathrm{mg})$ was weighed into a centrifuge tube and wetted with $1 \mathrm{ml}$ of $95 \%$ ethanol. $2 \mathrm{~mL}$ of distilled water was added followed by $10 \mathrm{~mL}$ of hot $95 \%$ ethanol. The content was vortexed and centrifuged (GALLENKOMP Centrifuge Model $90-1$, USA) at $2000 \mathrm{rpm}$ for $10 \mathrm{~min}$. The supernatant was decanted and used for determining sugar content while the sediment was hydrolyzed with perchloric acid and used to estimate starch content. Phenol- sulfuric reagent was used for colour development and glucose standards were used for estimation of sugar. The absorbance was read with a spectrophotometer (Milton Spectronic 601, USA ) at $490 \mathrm{~nm}$.

$$
\begin{aligned}
\% \text { Sugar } & =\frac{\text { Absorbance }-\mathrm{I}(0.0044)}{\text { sample wtx } 0.55} \\
\% \text { Starch } & =\frac{(\text { Absorbance }-0.0044) 4}{\text { sample wtx } 0.55}
\end{aligned}
$$

\section{Rheological properties of salad cream from corn and tigernut starch using Brookfield viscometer}

The method described by Muhammad and Sagir [18] was used for rheological properties of corn and tigernut starch. The viscosity of the salad cream samples was measured at a controlled temperature of $500{ }^{\circ} \mathrm{C}$ using a digital rotational Brookfield viscometer (Brookfield Engineering Laboratories, Middleboro, USA, Model DV - E). These readings were taken per samples at 20, 40 and 1 min rotation at each speed $(30,60$ and $100 \mathrm{rpm})$. Spindle \#4 was used for all measurements. A $600 \mathrm{ml}$ beaker was used for the measurement with the viscometer guard leg on. The samples were poured into a beaker to reach a level that covers the immersion groove on the spindle shaft. The viscosities of the products were measured at temperature between $25-26^{\circ} \mathrm{C}( \pm 1)$. 


\section{Sensory quality of salad cream made from corn and tigernut starch}

The method described by Iwe, [19] was used. Fifty Panelists from Federal University of Agriculture, Abeokuta (FUNAAB) was chosen for the sensory evaluation. The optimized sample of salad cream was presented to the panelists. The salad cream attribute that was evaluated were appearance, aroma, taste and spreadability. A 9 point Hedonic scale test was used to determine the overall acceptability of corn-tiger nut salad cream as $9=$ like extremely, $5=$ neither like nor dislike and $1=$ dislike extremely

\section{Statistical analysis}

All experimental data obtained were subjected to statistical analysis. Means, Analysis of variance were determined using SPSS version 21.0 and the difference between the mean values were evaluated at $p<0.05$ using Duncan multiple range test. The effect of optimization procedure was investigated using Design Expert version (8.0) and significant effects of the independent variables were determined at $5 \%$ confidence level.

\section{Results and discussion}

\section{blends \\ Proximate composition of salad cream produced from corn and tigernut starch}

The mean values of the proximate composition of salad cream produced from corn and tigernut starch blends presented in Table 1. Moisture content ranged from $51.50 \%$ to $59.58 \%$, corn-tigernut starch (50\%:50\%) had the lowest value, while corn-tigernut starch (70\%:30\%) had the highest value. The interaction effect of corn and tigernut starch does not have a significant ( $\mathrm{p}>0.05)$ effect on the moisture content of salad cream produced from corn and tigernut starch as shown in the regression coefficient of Table 2. The result obtained for moisture content of this study was higher than that reported by Babajide and Olatunde [20] in corn-cocoyam starch salad cream, who reported moisture content of 48.80 to $49.79 \%$. EkeEjiofor and Owuno [21] also reported a moisture content of 57.84 to $64.88 \%$ for cassava and potato starch based salad cream, which is similar to the result observed in this study. The moisture content of any food also indicates its level of water activity and thus, be used to measure its stability and susceptibility to microbial contamination [22]. The high moisture content of the salad cream obtained in this study can affect its quality and its shelf stability and this implies that the salad cream cannot be kept for a longer period of time. It can also lead to hydrolytic rancidity, which can cause off flavor of the salad cream. The different in the moisture content obtained in this study, may be attributed to the difference in the starch origin of the corn and tigernut crops. Total ash content varied between 0.33 and $0.58 \%$ with corn-tigernut starch $(90 \%: 10 \%)$ having the highest value, while corn-tigernut starch (10\%:90\%) had the least value. The regression coefficient shown in Table 2 shows that the interaction effect of corn and tigernut starch does not have a significant $(p>0.05)$ effect on the ash content of salad cream produced from corn and tigernut starch. The ash content of any given food sample is a measure of the mineral level that the food contains. There was a progressive increase in ash content with addition of corn starch in Table 1, which implies that salad cream with higher corn and tigernut starch $(90 \%: 10 \%)$ had more nutrients and this is beneficial to the health of the consumer. Total ash content obtained in this study was lower than the values of 0.50 to $4.10 \%$ and 1.74 to $2.75 \%$ reported by Oli et al. [23] and Ashaye et 
al. [24] on salad cream from yellow corn flour and cassava starch respectively but also similar to the values of 0.59 to $0.79 \%$ reported by Babajide and Olatunde [20] for corn-cocoyam starch salad cream. Crude fat ranged from 23.05 to $24.78 \%$ with corn-tigernut starch (30\%:70\%) having the least value while corn-tigernut starch (90\%:10\%) had the highest value. The interaction of corn and tigernut starch were not significantly $(\mathrm{p}>0.05)$ affected as shown in the regression coefficient in Table 2 The fat content of corn-tigernut starch salad cream had a similar value irrespective of blends combination. Fat plays a significant role in the shelf life of food products and as such relatively high fat content could be undesirable in food products. Eke-Ejiofor and Owuno [21] reported a fat content of 25.17 to $28.15 \%$ in cassava and potato starch based salad cream, while Babajide and Olatunde [20] reported a fat content of 27.04 to $29.68 \%$ in corn-cocoyam starch salad cream. These values are comparable to the result obtained in this study. Until recently, lipids have been considered as functional foods to enhance their analysis, extraction procedures or to enrich the nutritional profile of traditional foods [25]. However, the higher the fat content, the more tendency to promote rancidity, leading to development of unpleasant and odorous compounds. The protein content ranged from 0.65 to $1.16 \%$, salad cream with corn-tigernut starch (10\%:90\%) had the lowest value while salad cream with corn-tigernut starch (90\%:10\%) had the highest protein. Salad cream with higher proportion of corn and tigernut starch had higher protein and showed the influence of corn starch in the contribution of proteins. However, this should not be depended on because it does not determine the major source of protein. Proteins help to build and repair worn out tissues in the body. Studies of salad cream by Eke-Ejiofor, [26], Eke-Ejiofor and Owuno [21], Babajide and Olatunde [20], had lower protein values than what was obtained in this study. Thus values obtained in this study were far lower than the values of 1.40 to $8.75 \%$ reported by Oli et al. [23] and 1.55 to $1.80 \%$ reported by Naknaen et al. [27]. The carbohydrate content of the salad cream ranged between 14.31 and $23.41 \%$. Carbohydrate is a major nutrient that provides energy and helps promote healthy digestive system. Although the values obtained in this study was lower than the value of 7.11 to $17.32 \%$ reported by EkeEjiofor and Owuno [21] on potato starch and cassava starch based salad cream and 13.99 to $37.18 \%$ reported by Eke-Ejiofor and Beleya [28] on cassava, sweetpotato and three leaf yam starches

Table 1

Proximate composition of salad cream produced from corn and tigernut starch blends (\%)

\begin{tabular}{|c|c|c|c|c|c|}
\hline CS:TS & $\begin{array}{c}\text { Moisture } \\
\text { Content }\end{array}$ & $\begin{array}{c}\text { Total } \\
\text { Ash }\end{array}$ & $\begin{array}{c}\text { Crude } \\
\text { Fat }\end{array}$ & $\begin{array}{c}\text { Crude } \\
\text { Protein }\end{array}$ & Carbohydrate \\
\hline $10: 90$ & $56.92^{\mathrm{e}}$ & $0.33^{\mathrm{a}}$ & $23.07^{\mathrm{a}}$ & $0.65^{\mathrm{ab}}$ & $18.40^{\mathrm{c}}$ \\
\hline $90: 10$ & $57.57^{\mathrm{a}}$ & $0.58^{\mathrm{e}}$ & $24.78^{\mathrm{e}}$ & $1.14^{\mathrm{e}}$ & $15.93^{\mathrm{b}}$ \\
\hline $50: 50$ & $51.50^{\mathrm{c}}$ & $0.42^{\mathrm{c}}$ & $23.68^{\mathrm{c}}$ & $0.99^{\mathrm{c}}$ & $23.41^{\mathrm{f}}$ \\
\hline $70: 30$ & $59.58^{\mathrm{b}}$ & $0.55^{\mathrm{d}}$ & $24.53^{\mathrm{d}}$ & $1.03^{\mathrm{d}}$ & $14.31^{\mathrm{a}}$ \\
\hline $90: 10$ & $57.57^{\mathrm{a}}$ & $0.58^{\mathrm{e}}$ & $24.78^{\mathrm{e}}$ & $1.16^{\mathrm{e}}$ & $15.91^{\mathrm{b}}$ \\
\hline $30: 70$ & $53.69^{\mathrm{d}}$ & $0.38^{\mathrm{b}}$ & $23.23^{\mathrm{b}}$ & $0.75^{\mathrm{b}}$ & $21.95^{\mathrm{d}}$ \\
\hline $90: 10$ & $57.59^{\mathrm{a}}$ & $0.57^{\mathrm{e}}$ & $24.80^{\mathrm{e}}$ & $1.15^{\mathrm{e}}$ & $15.89^{\mathrm{b}}$ \\
\hline $10: 90$ & $56.94^{\mathrm{e}}$ & $0.35^{\mathrm{a}}$ & $23.05^{\mathrm{a}}$ & $0.67^{\mathrm{b}}$ & $18.99^{\mathrm{cd}}$ \\
\hline $50: 50$ & $51.52^{\mathrm{c}}$ & $0.44^{\mathrm{c}}$ & $23.68^{\mathrm{c}}$ & $1.01^{\mathrm{c}}$ & $22.75^{\mathrm{e}}$ \\
\hline
\end{tabular}

Mean values with different superscripts within the same column are significantly different $(\mathrm{p}<0.05)$; CS- Corn starch, TS- Tigernut starch 
Table 2

Regression coefficient of proximate composition of salad cream from corn and tigernut starch

\begin{tabular}{|c|c|c|c|c|c|}
\hline Parameters & MoistureContent & $\begin{array}{c}\text { Total } \\
\text { Ash }\end{array}$ & $\begin{array}{c}\text { Crude } \\
\text { Fat }\end{array}$ & $\begin{array}{c}\text { Crude } \\
\text { Protein }\end{array}$ & Carbohydrate \\
\hline A & 58.20 & 0.58 & 24.83 & 1.15 & 14.75 \\
\hline $\mathrm{B}$ & 56.59 & 0.34 & 23.02 & 0.65 & 19.32 \\
\hline $\mathrm{AB}$ & -16.51 & -0.064 & -0.71 & 0.24 & 17.54 \\
\hline F-VALUE & 3.45 & 93.49 & 122.58 & 94.34 & 5.92 \\
\hline $\mathrm{R}^{2}$ & 0.5348 & 0.9689 & 0.9761 & 0.9692 & 0.6639 \\
\hline
\end{tabular}

A- Corn starch, B-Tigernut starch, AB-Interaction of corn and tigernut starch, $\mathrm{R}^{2}$ - Coefficient of determination

\section{Physicochemical properties of salad cream produced from corn and tigernut starch blends}

The mean values and the interaction effect on the physicochemical properties of salad cream produced from corn and tigernut starch blends is presented in Table 3 and 4. Sugar and starch content of salad cream from corn and tigernut starch ranged from 2.67 to $9.50 \%$ and 4.14 to $11.45 \%$ respectively with salad cream from corn-tigernut starch (10\%:90\%) having the highest value for sugar and starch content while salad cream from corn-tigernut starch $(70 \%: 30 \%)$ had the least value for sugar and starch content respectively. The interaction effect of corn and tigernut starch had no significant $(\mathrm{p}>0.05)$ effect on the sugar contents as shown in Table 4. Sugar content was higher in salad cream from corn-tigernut starch (10\%:90\%), this may be attributed to high sucrose level. Sugar may also act as sweetener; thereby contribute to the taste and flavour of the salad cream. The interaction effect of corn starch and tigernut starch significantly $(p<0.05)$ affect the starch content of the salad cream negatively as shown in Table 4 . The starch content of salad cream ranged between 4.14 and $11.45 \%$ with corn-tigernut starch (10\%:90\%) having the highest value, while corn -tigernut starch (70\%:30\%) had the least value for starch content. The starch content obtained in this study was in range with the value of 8.03 to $12.25 \%$ and 6.40 to $14.41 \%$ reported by Ashaye et al. [24] and Eke-Ejiofor and Owuno [21]. The starch obtained in this study will helps to bind and thicken the salad cream together. It also helps in increasing the paste viscosity, emulsion stabilizers and it lowers gelatinization temperature. The $\mathrm{pH}$ of a food is defined as the level of acidity or alkalinity of food content. The $\mathrm{pH}$ of the salad cream ranged from 3.57 to 3.77 with corn-tigernut starch $(90 \%: 10 \%)$ having the lowest $\mathrm{pH}$ while corn-tigernut starch (10\%:90\%) had the highest $\mathrm{pH}$. Maximum desirable $\mathrm{pH}$ level for safety and optimum target $\mathrm{pH}$ should be 4.25 to ensure food safety [29]. $\mathrm{pH}$ of 4.5 is a desirable trait because it will halt the proliferation of micro-organism, thereby favoring the conservation of the in the final product [30,31]. However, the $\mathrm{pH}$ of corn-tigernut starch salad cream in this study was acidic. The $\mathrm{pH}$ of the salad cream obtained in this study was higher than the value of 3.14 to 3.50 reported by Eke-Ejiofor and Owuno [21] on salad cream from cassava and potato starch but lower than the value of 3.78 to 3.91 reported by Gaikwad et al. [32] on physicochemical properties of flavoured mayonnaise. The total titratable acidity of corn and tigernut starch salad cream ranged from 0.32 to $0.69 \%$, corn-tigernut starch (90\%:10\%) had the lowest value, while corn-tigernut starch (50\%:50\%) had the highest value of total titratable acidity. The total titratable acidity was significantly $(\mathrm{p}<0.05)$ affected by the interaction effect of corn and tigernut starch as shown in Table 4.Titratable acidity is a 
measure of food products acidity [15].The values of total titratable acidity obtained in this study was higher than the values of 0.02 to $0.89 \%$ reported by Eke-Ejiofor and Owuno [21] on cassava and potato starch based salad cream but lower than the values of 1.35 to $2.50 \%$ reported by Oli et al. [23] on salad cream from yellow corn flour. The difference obtained in total titratable acidity in this study could be due to the difference in starch properties between corn and tigernut crops. The viscosity of the salad ranged between 472 and 1683rpm with corn-tigernut starch $(90 \%: 10 \%)$ having the highest viscosity while corn-tigernut starch (10\%:90\%) had the lowest viscosity. However, the interaction effect of corn and tigernut starch on the viscosity of salad cream were significantly $(p<0.05)$ affected. The high viscosity obtained in corn-tigernut starch (90\%:10\%) could be due to the addition of the salad ingredients used in its preparation.

Table 3

Physicochemical properties of salad cream produced from corn and tigernut starch blends

\begin{tabular}{|c|c|c|c|c|c|}
\hline CS:TS & $\begin{array}{c}\text { Sugar } \\
\mathbf{( \% )}\end{array}$ & $\begin{array}{c}\text { Starch } \\
\mathbf{( \% )}\end{array}$ & $\mathbf{p H}$ & $\begin{array}{c}\text { Total } \\
\text { titratable acidity (\%) }\end{array}$ & $\begin{array}{c}\text { Viscosity } \\
\left(\mathbf{P a}^{*} \mathbf{s}\right)\end{array}$ \\
\hline $10: 90$ & $9.30^{\mathrm{e}}$ & $11.43^{\mathrm{a}}$ & $3.76^{\mathrm{a}}$ & $0.57^{\mathrm{c}}$ & $472^{\mathrm{a}}$ \\
\hline $90: 10$ & $3.39^{\mathrm{b}}$ & $4.87^{\mathrm{b}}$ & $3.57^{\mathrm{a}}$ & $0.32^{\mathrm{a}}$ & $1681^{\mathrm{e}}$ \\
\hline $50: 50$ & $6.56^{\mathrm{c}}$ & $7.01^{\mathrm{c}}$ & $3.68^{\mathrm{b}}$ & $0.68^{\mathrm{d}}$ & $1189^{\mathrm{cd}}$ \\
\hline $70: 30$ & $2.67^{\mathrm{a}}$ & $4.14^{\mathrm{a}}$ & $3.61^{\mathrm{a}}$ & $0.38^{\mathrm{b}}$ & $1412^{\mathrm{de}}$ \\
\hline $90: 10$ & $3.40^{\mathrm{b}}$ & $4.88^{\mathrm{b}}$ & $3.58^{\mathrm{a}}$ & $0.33^{\mathrm{a}}$ & $1683^{\mathrm{e}}$ \\
\hline $30: 70$ & $8.12^{\mathrm{d}}$ & $9.74^{\mathrm{d}}$ & $3.60^{\mathrm{ab}}$ & $0.56^{\mathrm{c}}$ & $990^{\mathrm{bc}}$ \\
\hline $90: 10$ & $3.41^{\mathrm{b}}$ & $4.89^{\mathrm{b}}$ & $3.58^{\mathrm{a}}$ & $0.35^{\mathrm{a}}$ & $1682^{\mathrm{e}}$ \\
\hline $10: 90$ & $9.50^{\mathrm{ef}}$ & $11.45^{\mathrm{a}}$ & $3.77^{\mathrm{c}}$ & $0.58^{\mathrm{c}}$ & $474^{\mathrm{a}}$ \\
\hline $50: 50$ & $6.57^{\mathrm{c}}$ & $7.02^{\mathrm{c}}$ & $3.67^{\mathrm{b}}$ & $0.69^{\mathrm{d}}$ & $1190^{\mathrm{cd}}$ \\
\hline
\end{tabular}

Mean values with different superscripts within the same column are

significantly different $(\mathrm{p}<0.05)$; CS- Corn starch, TS- Tigernut starch

Table 4

Regression coefficient of physicochemical properties of salad cream from corn and tigernut starch

\begin{tabular}{|c|c|c|c|c|c|}
\hline Parameters & Sugar & Starch & pH & Total titratable acidity & Viscosity \\
\hline A & 3.15 & 4.69 & 3.58 & 0.32 & 1670.29 \\
\hline B & 9.59 & 75.03 & 3.75 & 0.57 & 496.64 \\
\hline AB & -1.38 & $-5.36^{*}$ & -0.059 & $0.66^{*}$ & $497.10^{*}$ \\
\hline F-VALUE & 37.80 & 75.03 & 8.98 & 13.29 & 322.92 \\
\hline $\mathrm{R}^{2}$ & 0.9265 & 0.9616 & 0.7495 & 0.8158 & 0.9908 \\
\hline
\end{tabular}

A- Corn starch, B-Tigernut starch, AB-Interaction of corn and tigernut starch,

$\mathrm{R}^{2}$ - Coefficient of determination 


\section{blends}

Optimization process of salad cream produced from corn and tigernut starch

The salad cream was optimized based on some important properties attributed to salad cream. Moisture, total ash, crude fat, crude protein, carbohydrate, sugar, starch, $\mathrm{pH}$, total titratable acidity and viscosity were the main quality parameters studied in this work which were also the criteria based on desirability concept as well as their main quality parameters serving as the constraints to process optimization. Moisture, crude fat, carbohydrate, sugar, starch, $\mathrm{pH}$, total titratable acidity and viscosity were maximized while total ash and crude protein were set at none. The solution to the optimized salad cream from corn and tigernut starch blends is $90 \%$ corn starch and $10 \%$ tigernut starch as shown in Table 5.

Table 5

Solution process to the optimization of salad cream from corn and tigernut starch blends

\begin{tabular}{|c|c|c|c|c|c|c|c|c|c|c|}
\hline$\frac{\grave{\bar{d}}}{\bar{\Xi}}$ & $\tilde{z}$ & $\mathscr{\Omega}$ & 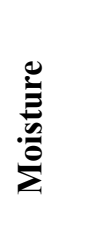 & 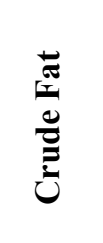 & $\stackrel{0}{\underline{U}}$ & 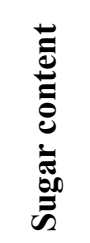 & 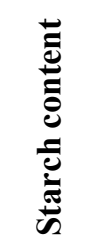 & 플 & 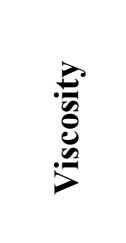 & 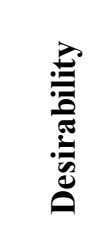 \\
\hline 1 & 90 & 10 & 58.20 & 24.83 & 14.75 & 3.154 & 4.685 & 3.58 & 1670.29 & 0.651 \\
\hline
\end{tabular}

CS- Corn starch, TS- Tigernut starch, CHO-Carbohydrate

\section{Sensory score of salad cream produced from corn and tigernut starch blends}

The sensory score of salad cream obtained from corn and tigernut starch blends is shown in Table 6.

Table 6

Sensory score of salad cream produced from corn and tigernut starch blends

\begin{tabular}{|c|c|c|c|c|c|}
\hline CS:TS & Appearance & Aroma & Taste & Spreadability & $\begin{array}{c}\text { Overall } \\
\text { acceptability }\end{array}$ \\
\hline $100: 0$ & $4.14^{\mathrm{a}}$ & $4.15^{\mathrm{b}}$ & $4.40^{\mathrm{a}}$ & $3.25^{\mathrm{a}}$ & $4.50^{\mathrm{a}}$ \\
\hline $90: 10$ & $6.55^{\mathrm{b}}$ & $6.85^{\mathrm{c}}$ & $6.90^{\mathrm{b}}$ & $6.10^{\mathrm{b}}$ & $6.95^{\mathrm{c}}$ \\
\hline $\begin{array}{c}\text { Commercial } \\
\text { (HeinzSalad } \\
\text { Cream) }\end{array}$ & $7.10^{\mathrm{b}}$ & $5.75^{\mathrm{b}}$ & $4.90^{\mathrm{a}}$ & $7.00^{\mathrm{c}}$ & $6.00^{\mathrm{b}}$ \\
\hline
\end{tabular}

Mean values with different superscripts within the same column are significantly different $(\mathrm{p}<0.05)$; CS- Corn starch, TS- Tigernut starch

Consumer quality is a major factor for selecting a product and among the main characteristics related to quality are texture, taste, and surface color of foods [33]. Significant difference $(p<0.05)$ was observed in all the sensory attribute of salad cream produced from corn and tigernut starch blends. Appearance, aroma, taste, spreadability and overall acceptability ranged from 4.14 to $7.10,4.15$ to $6.85,4.40$ to $6.90,3.25$ to 6.10 and 4.50 and 
6.95 respectively. Optimized salad cream had the highest value for aroma, taste and overall acceptability, commercial salad cream had the highest for appearance and spreadability while salad cream produced from $100 \%$ corn starch had the least for all attributes. Aroma, taste and overall acceptability of optimized salad cream were most preferred over commercial salad cream and $100 \%$ corn starch salad cream with a sensory score of $6.85,6.90$ and 6.95 respectively. Commercial salad cream had higher sensory scores in terms of appearance and spreadability. Meanwhile, $100 \%$ corn starch salad cream showed a very poor sensory attributes and was rejected by the panelist.

\section{Conclusions}

1. Salad cream from corn and tigernut starch had desirable physicochemical properties and has a compared sensory attributes with the commercial salad cream, especially for appearance.

2. However, $100 \%$ corn starch based salad cream was rated low. Therefore, an acceptable salad cream can be produced up to $10 \%$ substitution of tigernut starch with corn starch thereby increasing the utilization of tigernut starch.

\section{References}

1. Moorthy S.N. (1996), Starch and starch derivatives in food, Trends Carbohydrate Chemistry, 425, pp. 133-139.

2. Le CorreD., BrasJ., DufresneA. (2010), Starch nanoparticles: A Review, Biomacromolecules, 11, pp. 1139-1153.

3. Adama K.K., Afolayan M.O., Oberafo A.A., Thomas S. (2014), Isolation and physicochemical characterization of tigernut (Cyperusesculentus) starch as a potential industrial Biomaterial, International Journal of Materials Science and Applications, 3(2), pp. 37-41.

4. Brown W.H., Poon T. (2005), Introduction to organic chemistry ( $3^{\text {rd }}$ ed.), Wiley.

5. Osundahunsi O., Fagbemi T.N., Kesselman E., Shimoni, E. (2003), Comparison of the physicochemical properties and pasting characteristics of flour and starch from red and white sweetpotato cultivars, Journal of Agricultural and Food Chemistry, 51(8), pp. 2232-2236.

6. OdoemelanS.A. (2003), Chemical composition and functional properties of conophor nut flour (Tetracarpidiumconophorum) flour, International Journal of Food Science and Technology, 38, pp. 729-734.

7. Belewu M.A., Belewu K.Y. (2007), Comparative physicochemical evaluation of tigernut, soybean and coconut milk sources, International Journal of Agriculture and Biology, 5, pp. 785-787.

8. FAO (1988), Traditional food plants, Food and Nutrition Paper,42, pp.239-242.

9. Coskuner Y., Ercan R., Karababa E., Nazlican A.N. (2002), Physical and chemical properties of chufa (Cyperusesculentus L) tubers grown in the Cukurova region of Turkey, Journal of the Science of Food and Agriculture, 82, pp. 625-31.

10. Ranken M.D., Christopher G.J., Baker R.C. (2015), Google books, Food industries Manual 2015-08-14.

11. Turgeon S.L., Senchez C., Gauthier S.I., Puguin, P. (1996), Stability and rheological properties of salad dressing containing peptidic fractions of whey protein, International Diary Journal, 6, pp. 645-658. 
12. Yao N., Paez A.V., White P.J. (2009), Structure and function of starch and resistant starch from corn with different dose of mutant amylose-extruder and floury-1 alleles, Journal of Agriculture and Food Chemistry, 37(5), pp.2040-2048.

13. Sanni L.O., Maiya-Dixon B., Onabolu A.O., Arowosafe B.E., Okoruwa A.E., Okechukwu R.U., Geteloma C. (2006), Cassava recipe for household for food security, International Institute for Tropical Agriculture IITA. Integrated Cassava Project, Ibadan. Nigeria, p. 30.

14. A.O.A.C (2010), Official Methods of Analysis, $17^{\text {th }}$ ed. Association of Analytical Chemists, Washington, D.C, USA.

15. Patterson S.P., McWatters K.H., Hung Y.C., Chinnan M.S., Phillips R.D. (2002), Physico-chemical properties and consumer acceptability of akara (fried paste) made from three cowpea cultivars, Food Research International, 35(7), pp. 691-696.

16. Dubois M., Gilles K.A., Hamilton J.K., Reberts P.A., Smith F. (1956), Colorimetric method for determination of sugar and related substances, Analytical chemistry, 28, pp. 350-356.

17. Eke-Ejiofor J., Kin-Kabari D.B. (2010), Chemical properties of sweet and Irish potato chips, Nigerian Food Journal, 28(2), pp. 47-52.

18. Muhammad S., Saghir A.S. (2011), Analysis of viscosity of jamun fruit juice, squash and jam at different compositions to ensure the suitability of processing applications, International Journal of Plant Physiology and Biochemistry, 3(5), pp. 89-94.

19. Iwe M.O. (2002), Handbook of Sensory Methods and Analysis, Rojoint Communication Publishers Ltd, Enugu.

20. Babajide J.M., Olatunde O.O. (2010), Proximate composition, rheology and sensory qualities of corn-cocoyam salad cream, World Journal Dairy and Food Science, 5(1), pp.25-29.

21. Eke-Ejiofor J., Owuno F. (2014), The functional properties of starches, physicochemical and sensory properties of salad cream from cassava and potatoes, International Journal of Nutrition and Food Sciences, 3 (6), pp. 567-571.

22. Edem C.A., Dosunmu, M.I. (2011), Chemical evaluation of proximate composition, ascorbic acid and anti-nutrients content of African star apple (Chrysophyllumafricanum) fruits, International Journal of Recent Research and Applied Studies, 9 (1), pp. 146-156.

23. Oli C.C., Ezeudu E.C., Okoye O.N.N. (2017), Study on the physicochemical properties and sensory evaluation of salad creams made from locally available raw materials, IDOSR Journal of Scientific Research, 2(3), pp. 26-35.

24. Ashaye O.A., Lateef S.O., Arowosafe E.B. (2010), Physiochemical rheological and consumer acceptability of cassava starch cream, Journal of American Science, 6(1), pp.65-72.

25. Cinzia B., Patrizia R. (2012), Lipids in functional foods, nutraceuticals and supplements. European Journal of Lipid Science and Technology, 114(4), pp. 369-371.

26. Eke-Ejiofor J. (2015), Physico-chemical and pasting properties of starches from cassava, sweet potato and three leaf yam and their application in salad cream production, International Journal of Biotechnology and Food Science, 3(2), pp. 23-30.

27. Naknaen P., Chinnapitiwong N., KruayooP. (2018), Enhancing the quality attributes of salad dressing by incorporating Gac aril as a biologically active ingredient, Brazilian Journal of Food Technology, 21, e2017129.

28. Eke-Ejiofor J., Beleya E.A. (2015), Effect of packaging materials on the storage conditions of salad cream from cassava, sweet potato and three leaf yam starches, International Journal of Biotechnology and Food Science,3(5), pp. 57-62. 
29. Anthon G.E., Strange M.L., Barrett M.D. (2011), Changes in pH, acids, sugars and other quality parameters during extended vine holding of ripe processing tomatoes, Journal of the Science of Food and Agriculture, 91 (7), pp.1175-1181.

30. Campos R.M.L. de., Hierro E., Ordonez J.A., Bertol T.M., Hoz L. de la, (2006), A note on partial replacement of maize with rice bran in the pig diet on meat and backfat fatty acids, Journal of Animal Feed Science, 15 (3), pp. 427-433.

31. Monteiro M.S., Rocha E., Fontainhas-Fernandes A., Sousa M. (2008), Quantative histopathology of Orechromisniloticus gill after copper exposure, Journal of Fish Biology, 73, pp.1376-1392.

32. Gaikwad M.P., Syed H.M., Shinde D.D. (2017), To study the physico chemical properties of flavoured mayonnaise, Journal of Pharmacognosy and Phytochemistry, 6(5), pp. 06-09.

33. Omoba O.S., Omogbemile A. (2013), Physicochemical Properties of sorghum biscuits enriched with defatted soy flour, British Journal of Applied Science and Technology, 3(4), pp. 1246-1256. 